in North America and these faunas appear at exactly the same time in both areas. In discussion with Opdyke, I have used the genus Allophaiomys as an example because it appears in abundance in both Biharian and Irvingtonian faunas; its cheek teeth are rootless and its earliest records in North America are above a 2.0-Myr ash in Kansas and during the Olduvai Subchron in Saskatchewan. This is in explanation of the statements of Opdyke et al.; Allophaiomys was not mentioned in our letter ${ }^{3}$. As mentioned by Opdyke et al., Allophaiomys occurs in the Brielle boring of The Netherlands ${ }^{6}$ and this fauna was mentioned in our letter.

But the Brielle boring contains two faunas. Allophaiomys occurs at a depth of $57-58 \mathrm{~m}$ and is assumed to be associated with an Eburonian flora ${ }^{6}$ : a record that has impressed Opdyke et al. The rootless microtine Dicrostonyx occurs in the Brielle boring at a depth of $65-66 \mathrm{~m}$ and is associated with a Tiglian C-6 flora; Dicrostonyx also first occurs in the earliest Biharian faunas of Europe ${ }^{4}$. The fauna from the Egypte channel in The Netherlands ${ }^{7}$ contains only microtines with rooted cheek teeth, is associated with a Tiglian C-5 flora, and is channeled into beds with a Tiglian C-4 flora ${ }^{7}$; the Egypte channel fauna is a Villanyian fauna. Thus the Villanyian-Biharian boundary is rather closely tied to either the lowest Tiglian C-6 or the highest Tiglian C-5. Tiglian C-6 is oldest Olduvai Subchron and Tiglian C-5 is basal Olduvai and preOlduvai reversely magnetized ${ }^{8,9}$. The base of the Olduvai is close to $1.9-\mathrm{Myr}$ old and so is the Villanyian-Biharian boundary in Europe. However, we did show ${ }^{3}$ the base of the Olduvai a bit too young on our Fig. 1 according to current refinements of the age of KBS Tuff in East Africa.

CHARLES A. REPENNING

US Geological Survey,

345 Middlefield Road,

Menlo Park, California 94025, USA

1. Prevot, M. \& Dairymple, G. B. C. r. hebd. Séanc. Acad. Sci., Paris 271, 2221-2224 (1970).

2. Gromme, C. S. \& Hay, R. L. Earth planet. Sci. Lett. 10, 179-185 (1971).

3. Repenning, C. A. \& Fejfar, O. Nature 299, 344-347 (1982).

4. Fejfar, O. \& Heinrich, W.-D. Eclog. geol. Helv. 74, 997 1006 (1981).

5. Kretzoi, M. Földt. Közl. 71, 308-335 (1941).

6. van der Meulen, A. J. \& Zangwijn, W. H. Scripta Geol. 21, 1-12 (1974).

7. Freudenthal, M., Meijer, T. \& van der Meulen, A. J. Scripta Geol. 34, 1-27 (1976)

8. van Montfrans, H. M. Earth planet. Sci. Lett. 11, 226-235 (1971).

9. Brunnacker, K., Loscher, M. Tillmanns, W. \& Urban, B Quat. Res. 18, 152-173 (1982)

\section{Disruptive or directional selection?}

AN elegant experiment on larval competition using unmarked, unselected strains of Drosophila melanogaster has been described by Pérez-Tomé and Toro ${ }^{1}$. Vials containing 10 unrelated full-sibships produced more adult flies than did vials containing 10 full-sibships related as half- sibs through a common father. The authors interpret this result as indicating that larvae with relatively similar genotypes compete with each other more directly than do larvae with relatively dissimilar genotypes, and they suggest that this supports the view that significant amounts of genetic variation are maintained in nature by frequency-dependent disruptive selection arising from differential resource utilization by different genotypes within the same local population. Here we point out that there is another possible interpretation of their results. On this interpretation, selection is strictly directional.

The larvae were extremely crowded. If a female laid approximately one egg per $\mathrm{h}$, the average egg-to-adult survival in this experiment was less than $20 \%$. The population was derived from a large number of ancestors that had been collected from the wild in September 1981. Thus, it seems likely that the population contained substantial genetic variation for characters affecting larval survival in crowded conditions on artificial medium. If such variation was preserit, the results presented by Pérez-Tomé and Toro can be explained without invoking genotypespecific interactions between larvae, or differential utilization of niches. For simplicity, consider a single locus at which there is an unconditionally favorable allele $A$ at frequency $p$. The expected frequency of $A$ among the eggs in any vial is always $p$, because parents are always selected at random. But the variance of $p$, over vials, is greater in the 'homogeneous series', where there is only one father per vial, than it is in the 'heterogeneous series', where each of the 10 full-sibships has a different father. (In the multi-locus case, the variance of $\bar{p}$ is also greater in the homogeneous series than in the heterogeneous series.)

By assumption, the number of adults emerging from a vial is an increasing function of the actual frequency of $\boldsymbol{A}$ among the eggs laid in that particular vial. But suppose this number obeys a law of diminishing returns, due to the limited amount of food and space available. It follows that the mean number of adults emerging should be greater for vials in the heterogeneous series than for those in the homogeneous series, because more adults are lost from vials in which the actual frequency of $A$ is below $p$, than are gained from vials in which the frequency of $A$ is above $p$. This is also expected on the disruptive-selection model, of course, and was the main experimental finding (Table 1 of ref. 1). The directional-selection model makes the additional prediction that the variance of the number of adults emerging per vial should be greater for vials in the homogeneous series than for those in the heterogeneous series. This difference is not demanded by the disruptive-selection model, but might easily appear in a differential niche-utilization version of it. The difference does appear in the data $(F(120,120)=3.5 P<0.001$, for the overall variances in Table 1 of ref. 1).

It seems entirely possible that disruptive selection (of the kind discussed by Pérez-Tomé and Toro) and directional selection (of the kind discussed here) both occured in this experiment. We do not see how the directional-selection effect can be ruled out, in any experiment in which there is genetic variance between vials within series.

KEVIN FOWLER JON SEGER

Population Biology Group,

School of Biological Sciences,

University of Sussex,

Falmer, Brighton BN1 9QC, UK

1. Pérez-Tomé, J. M. \& Toro, M. A. Nature 299, 153-154 (1982).

TORO AND PÉREZ-TOMÉ REPLY - The alternative explanation suggested by Fowler and Seger assumes: (1) the existence of an unconditionally favourable allele $\boldsymbol{A}_{\mathrm{i}}$ affecting larval survival; (2) the number of adults emerging from a vial is an increasing function of the actual frequency, following a law of diminishing returns. Nevertheless, we fail to see how this law can be accomplished in a system of strict density-dependent selection, as diminishing returns would generally imply frequency-dependent selection. The convexity of the function $f(w, p)$ would only arise if $w_{i j, k} \neq w_{i j, k^{\prime}}$ (where $w_{i j, k}$ is the fitness of the $i j$ th genotype in the $k$ th family. This is the case of frequency-dependent selection either by genotype-specific interactions between larvae or by differential utilization of niches. But in the usual density-dependent model ${ }^{1} w_{i j}=$ $v_{i j} /\left(1+a_{i j} N\right)$ (where $v=$ viability, $v / a=$ carrying capacity, $N=$ number of eggs per vial) and there is no way for the convexity to arise.

A density-dependent selection model would only mimic frequency dependence when $w_{i j}=v_{\mathrm{ij}} /\left(1+a_{i j} \bar{v}\right.$ ) (where $\bar{v}=$ family mean egg-larvae viability). This would imply the existence of genes of large effect on viability or more exactly on the nondensity-dependent component of fitness. In any case, this last possibility could be ruled out almost completely if our results can be repeated by using larvae directly instead of fecundated females. This experiment is now in progress.

\section{A. TORO}

Departamento de Genetica Cuantitativa, Instituto Nacional de Investigaciones, Agrarias, Carretera de La Coruna Km. 7, Madrid-35, Spain

J. M. PEREZ-TOMÉ Collegio Universitario Arcos de Jalon, Arcos de Jalon, s/n, Madrid-17, Spain

1. Maynard Smith, J. \& Hoekstra, R. Genet. Res., Camb. 35, 45-57 (1980). 